\title{
REALIZATION OF THE ELECTRIFICATION PLAN IN TURKESTAN $\left(20^{T H}\right.$ YEARS OF THE XX CENTURY)
}

\author{
Saidboboeva Gulzora Nematjonovna \\ PhD, Department of History source and archival studies of National University of Uzbekistan
}

Article DOI: https://doi.org/10.36713/epra8420

DOI No: 10.36713/epra8420

\begin{abstract}
The article describes the state of electrification in Turkestan during the Soviet era on the basis of statistical materials, scientific literature and archival documents $\left(20^{\text {th }}\right.$ years of the $X X$ century). The author also analyzes the engineers who took an active part in this process in the country and their participation in the electrification of the regions.
\end{abstract}

\section{DISCUSSION}

In realizing the GOELRO plan in Turkestan, the central offices of the Union had to do a number of things. Due to the fact that electrification in the transition period was planned to be carried out on a planned farm, it was confronted with the specifics of the districts, which consisted of "designing large district centers and developing district economic plans as part of a single national plan" [1:1].

Turkestan is divided into four economic regions - Fergana, Chirchik-Mirzachul, Zarafshan, Yettisuv. Plans have been drawn up for each of them, taking into account the development of electrification, irrigation and industrial construction.

The plan for electrification of the Turkestan economic region was approved by the GOELRO commission. G.K. Rizenkamf (chairman), V.D. Jurin (who developed the electrification plan of the Fergana valley), V.M. Buzinova (prepared written report "Electrification of Chirchik and Mirzachul districts"), A.M. Yestifeev (prepared written report "Electrification of Zarafshan region"), E.E. Skornyakov (prepared a written report "Electrification of the Yettisuv region"), prepared by V.V. Zaorskaya-Alexandrova (using the work "Economic plate of the Turkestan region") and others. As consultants, I.G. Aleksandrov, A. V. Chaplygin, G.D. Dubemr, R.A. Ferman, E.Ya. Shulgin is included.

According to the GOELRO plan, in order to electrify the national republics, in particular Turkestan, in March 1921, its own executive body and the Committee for the Electrification of Turkestan, which had 70 million rubles at its disposal, were established [2:24].

In late 1921-early 1922, the Commission on Electrification of the Republic of Turkestan began its work in Tashkent. The commission continued the work of the Electrification Committee set up in the hydropower department of the Central Economic Council of Turkestan. According to the Regulations on the Electrification Commission of Turkestan, it is entrusted with the following tasks: a) to draw up a general plan of electrification of the Republic of Turkestan for the next 10 years; b) development of a project to increase the performance of existing electrical equipment; c) creation of cadastre of energy sources (water, coal, oil, etc.); g) promotion and dissemination of the electrification plan [3:97].

As a key part of the overall plan to electrify Turkestan, G.K. Riesenkamf's "Program for the establishment of cotton growing in Turkestan" was also adopted. The forecast of the development of economic life of the region, the network of power plants and power transmission lines in the region, the work to determine the periodic sequence of the electrification plan belong to him. The general explanatory letter is from the team of engineers consultant It was developed by R.A. Ferman and he was also commissioned to write a review of the plan [4:17].

Given the low level of energy supply in Turkestan, the developers of the GOELRO plan said: "It is absolutely inappropriate to talk about 'supplying 
electricity to neighboring areas from existing power plants' because the electricity supply in Turkestan is so low and its capacity is insignificant" [5:642].

The resolution on electrification of Turkestan (April 25, 1922) focused on the electrification of cultural centers, the use of existing facilities and the restoration of old irrigation systems, the development of electrification plans and the establishment of a special energy section under the Turkestan State Planning Committee [6:542].

There are no plans to build power plants in the Yettisuv district in the first place. In the second phase, it is planned to build the Atbashi HPP with a capacity of $3,000 \mathrm{~kW}$, the main canal water pumping station at Jilarik station with a capacity of 30,000 $\mathrm{kW}$, and the Alamedin HPP with a capacity of several thousand $\mathrm{kW}$ on the Alamedin River [7:644647].

It should be noted that the Caspian region and the northern part of the Syrdarya region are not included in the plan to electrify Turkestan. Because in these regions there were no economic factors that required the need for electrification at the state level [8:644].

After studying the rich water resources of Fergana region, the special commission considered that it was possible to build three power plants there as well [9:94]. Initially, it is planned to build a single power plant for the Fergana region near Uchkurgan on the Naryn River with a capacity of $30,000 \mathrm{~kW}$, and then $80-100$ thousand $\mathrm{kW}$. It is possible to build a dam up to 10 meters high in the upper reaches of the river, which will create a pressure of up to 30 meters, the water flow of the river will vary from 170 $\mathrm{m}^{3}$ to $3100 \mathrm{~m}^{3}$, thus providing power to the entire Fergana Valley. reported to take about 4 years [10:644].

It is planned to build two main stations for the Chirchik-Mirzachul region: the projected Chirchik canal at the Bozsuv stream, in the north of the region initially with a capacity of about $30,000 \mathrm{~kW}$, and then expanded to about $60-80$ thousand $\mathrm{kW}$, and in the northern Mirzachul region and in the south. Bekabad station with a capacity of 18 thousand $\mathrm{kW}$ for part [11:645].

There were 11 power plants with a production capacity of 38,039 rubles, 18 mechanical engines, and 989 horsepower[12:217].

Mirzachul district, according to preliminary estimates, it is planned to spend 30 million for construction, 56 for agriculture, 125 for industry, 15 for cities and settlements, a total of 226 million $\mathrm{kWh}$ [13:226].

Electrification of the $350 \mathrm{~km}$ long TashkentAris and Tashkent-Pskent-Dalvarzin railways doubled the volume of freight traffic in 1912 to 80 million pounds. An additional 20 million pounds of cotton will be transported from Chirchik and Mirzachul districts, and 20 million pounds from Fergana alone. It was also possible to transport construction materials.

In particular, in Chirchik district $10000 \mathrm{kWh}$ of electricity is intended for construction, 1000 for agriculture, 95670 for heavy industry, 20000 for other consumers (small industry), 66000 for cities and settlements, 26200 thousand $\mathrm{kWh}$ for electrification of telegraph lines [14:223].

A.M. Yestifeev's report on the electrification of the Zarafshan region states that electricity is required first for irrigation works and earthworks for irrigation canals and in artificial constructions for mechanized irrigation, and then in agriculture: the use of energy for plowing, plowing, planting, weeding, harvesting - It should be noted that the harvest and, finally, the processing of raw materials such as cotton, grain, grapes, vegetables from irrigated lands should serve industrial enterprises, it is possible to operate different plants from each of these types of raw materials [15:259].

I.G. Alexandrov, a member of the commission who is well aware of the energy potential of the Chirchik-Chatkal basin. put forward the idea of launching the production of synthetic nitrogen fertilizers using cheap hydropower to develop cotton growing in the Central Asian republics. He proposed to build an electrochemical complex and Chirchik electrochemical plant from the cascade of hydropower plants on the Chirchik River [16:17].

Thus, for the whole of Turkestan, first of all, 5 regional stations with a capacity of about 80-100 thousand $\mathrm{kW}$, and secondly, 6 stations (including one station on the Sokh River in Fergana region) and 100-170 thousand $\mathrm{kW}$ due to the expansion of the total capacity of the first stations designed to generate electricity $[17: 647 ; 31]$.

In the study of the general plan for the electrification of Turkestan, it was planned to build dozens of large hydropower facilities for its time, which, according to the authors, would serve the restoration of the country, the growth of its economy and culture. Despite the urgency of the plans, the GOELRO plan, approved by the VIII All-Russian Congress of Soviets, included the construction of a hydroelectric power station in the Tashkent region in the first place. According to the initial version of the GOELRO plan, the total capacity of the hydropower plant in Turkestan was to be $12.5 \%$ of the total electricity in the planned country [18:18]. The remaining power plants, which were originally planned to be built by the GOELRO commission, were not included in the government-approved plan. This is explained by the inadequacy of the material and technical base of the country in 1920, the inability to build all the power plants specified in the GOELRO plan. 
The Electrification Commission concluded that the expansion of Turkestan was facilitated by the expansion and facilitation of trade relations with neighboring regions - Siberia, Kuldja, Kashgar, Afghanistan, Iran and the south-east of Russia, as well as the construction of railways connecting them [19:23].

The GOELRO commission came to the following conclusions on the electrification of agriculture in Turkestan:

1. For the restoration and development of the country's productive forces it is necessary, first of all, to carry out a great deal of work on irrigating the lands, while artificial raising of water, i.e. mechanized irrigation, can only be solved on the basis of electrification.

2. Extensive mechanization of agricultural production on the basis of electrification is required.

3. Restoration and further development of cotton growing, which is the basis of the national economy of the country, can only be on the basis of electrification.

It is obvious that the electrification of the Turkestan region is closely connected with irrigation, without which there could be no talk of raising cotton growing. Therefore, the GOELRO plan reflects the emergence of three crucial links of the national economy - electrification, irrigation, cotton growing, which are interrelated and interdependent.

The construction of a system of large power plants across the country envisages the integrated use of its vast natural resources and labor resources. The fuel industry has considerably strengthened its influence in the new districts. Coal production increased slightly in Central Asia and Kazakhstan [20:244].

In 1923, the supply of oil and coal was regulated, and electric power plants were put into operation at the enterprises. As a result, productivity has increased significantly. In the same year, the construction of Fergana and Margilan power plants began, as well as in Bukhara, Kokand, Termez and Karshi [21:34; 94].

At the request of the Turkestan ASSR government, the chairman of the State Planning Committee (Gosplan), G.M. In 1923, Krzyzanovsky set up a special commission of well-known experts to determine the possibility of building a hydroelectric power station in Tashkent, which is part of the GOELRO plan. After a positive solution to this issue, the government of the RSFSR allocated 350 thousand rubles for the construction of the Bozsuv hydroelectric power station [22:250-251].

The GOELRO plan, which envisages a largescale hydraulic construction program in its time, served as a basis for the comprehensive and planned use of hydropower from rivers. The project for the construction of a hydroelectric power station on the
Bozsuv River, submitted on July 31, 1923 by the power section of the Central Electrotechnical Council (CSC), recognized the expediency of supplying Tashkent with electricity noted the presence of [23:543].

The construction of the Bozsuv HPP has started the development of a school for the training of hydropower and the rich hydropower resources of the republic. The construction of the station has paved the way for large-scale development of rich hydropower in Uzbekistan [24:277]. The newspaper of "Turkestanskaya Pravda" published a report on the construction of a power plant in Bozsuv on May 23, 1923: "The work is going well. The main gateway is ready to block the riverbed " [25:24].

The State Planning Committee of the USSR confirmed the economic and technical importance of the Bozsuv hydroelectric power plant and pointed out the need to increase funding for its construction. On February 20, 1924, the Labor and Defense Council accepted for information the proposal of the Turkestan government to allocate 350,000 rubles for the construction of a power plant, and 600,000 rubles from local funds [26:543].

In 1923-1924, the number of power plants in Turkestan was 31, in the Georgian ASSR 31, in the Ukrainian ASSR 91, and in the RSFSR 851, indicating that the country did not pay much attention to the electricity industry [27:588].

According to the 1924 issue of Turkestanskaya Pravda, the construction of a 2,000$\mathrm{kW}$ station in the Dalvarzin Desert to electrify and irrigate the city of Merv at the expense of $400 \mathrm{~kW}$ of power from the Hindu Kush hydroelectric power station will produce nitrogen fertilizer. It was hoped that this would alleviate the difficulties faced by the country's cotton industry [28].

The above data show that electrification measures in the country have been carried out at the expense of increasing the production of agricultural raw materials, and insufficient attention has been paid to industry and the social sphere. The electrification of Turkestan was an integral part of the plan to electrify the entire Union. The idea of electrification is not only to make profound changes in all sectors of the economy - industry, agriculture and transport, but also to cover the entire territory of the country, all republics, regions and districts in a single centralized electrification plan, which in practice makes the country economically dependent, served to strengthen.

\section{BIBLIOGRAPHY}

1. Economic regionalization of Russia. Report of the State Planning Committee of the III Session of the All-Russian Central Executive Committee. - Moscow: 
Edition of the All-Russian Central Executive Committee, 1922.

2. National Archives of Uzbekistan, R-25-fund, 1register, 106-case.

3. On the Commission for the Electrification of the Turkestan Republic // Izvestia. December 1, 1921 No. 271; Karimov R.Kh. Uzbekistan during the restoration of the national economy of the USSR (1921-1925) - Tashkent: "Uzbekistan", 1974.

4. Matniyazov M. Electrification and its social consequences (Based on the materials of the republics of Central Asia). - Tashkent: "Uzbekistan", 1984.

5. The plan for the electrification of the RSFSR (Report to the VIII Congress of Soviets of the State Commission for the Electrification of Russia). Second edition. - Moscow: State. publishing house of political literature, 1955.

6. Development of the electrification of the Soviet country in 1921-1925. - Moscow: State. publishing house of political literature, 1956.

7. The plan for the electrification of the RSFSR (Report to the VIII Congress of Soviets of the State Commission for the Electrification of Russia). Second edition. - Moscow: State. publishing house of political literature, 1955.

8. Plan for the electrification of the RSFSR (Report to the VIII Congress of Soviets of the State Commission for the Electrification of Russia). Second edition. Moscow: State. publishing house of political literature, 1955.

9. National Archives of Uzbekistan, R-25-fund, 1register, 346-case.

10. The plan for the electrification of the RSFSR (Report to the VIII Congress of Soviets of the State Commission for the Electrification of Russia). Second edition. - Moscow: State. publishing house of political literature, 1955. - P. 644.

11. The plan for the electrification of the RSFSR (Report to the VIII Congress of Soviets of the State Commission for the Electrification of Russia). Second edition. - Moscow: State. publishing house of political literature, 1955.

12. Buzinova V.M. Electrification of Chirchik and Golodnostep districts // Proceedings of the State Commission for the Electrification of Russia GOELRO. Materials on the electrification of certain areas. - Moscow: "Science", 1964.

13. Buzinova V.M. Electrification of Chirchik and Golodnostep districts // Proceedings of the State Commission for the Electrification of Russia GOELRO. Materials on the electrification of certain regions. - Moscow: "Science", 1964.

14. Buzinova V.M. Electrification of Chirchik and Golodnostep districts // Proceedings of the State Commission for the Electrification of Russia GOELRO. Materials on the electrification of certain regions. - Moscow: "Science", 1964.

15. Yestifeev A.M. Electrification of the Zeravshan region // Proceedings of the State Commission for the Electrification of Russia GOELRO. Materials on the electrification of certain regions. - Moscow: "Science", 1964. - P. 259.

16. Matniyazov M. Electrification and its social consequences (Based on the materials of the republics of Central Asia). - Tashkent: "Uzbekistan", 1984. - P. 17.

17. Plan for the electrification of the RSFSR (Report to the VIII Congress of Soviets of the State Commission for the Electrification of Russia). Second edition. Moscow: State. publishing house of political literature, 1955. - P. 647; Electrification of the Turkestan region. Compiled by the State Electrification Commission of Russia. - Moscow, 1920 .

18. Burdin E.A. Hydropower in the GOELRO plan (1920-1935) // Bulletin of UlSTU. - Ulyanovsk, 2010. - No. 1.

19. Electrification of the Turkestan region. Compiled by the State Electrification Commission of Russia. Moscow, 1920.

20. Lenin's plan for socialist industrialization and its implementation / Ed. board: P.N. Pospelov (leader) and others - Moscow: Politizdat, 1969.

21. Ziyadullaev S.K. Industry of Uzbekistan and the main economic problems of its development. - Tashkent: "Fan", 1967; R.Kh. Karimov Uzbekistan in the period of restoration of the national economy of the USSR (1921 - 1925) - Tashkent: "Uzbekistan", 1974.

22. Abdushukurov R.Kh. The October Revolution, the dawn of the Uzbek socialist nation and its rapprochement with the nations of the USSR. Tashkent: State Publishing House of the UzSSR, 1962.

23. Development of the electrification of the Soviet country in 1921-1925. - Moscow: State. publishing house of political literature, 1956.

24. Desyatchikov B.A. Ozbekistonni elektrlashtirish. Toshkent: Uzdavnashr, 1949; Yu.V. Steklov IN AND. Lenin and electrification. - Moscow: "Science", 1970.

25. Pulatova M. Industry of the TASSR in the years of transition to the NEP // "Social Sciences in Uzbekistan". - Tashkent, 1968. - No. 4.

26. Development of the electrification of the Soviet country 1921-1925. - Moscow: State. publishing house of political literature, 1956.

27. Industrial Russia 1923-1924 Reference book. Publishing of the newspaper "Economic Life". Leningrad, 1924.

28. Development of power construction in Turkestan // Turkestanskaya Pravda. July 24, 1924, No. 160 (473). 